\title{
最近の計装技術 (II)
}

本州製紙㑣 本 間 忠 一

\section{Recent Development of Instrumentation in Pulp \& Paper Industry}

\section{Chuichi Honma}

Honshu Paper Co., Ltd.

This paper describes latest instrumentation in pulp \& paper industry, especially this month in sensors followed last month.

Keywords : Instrumentation $\cdot$ Sensors

\subsubsection{2 (前号からの続き)}

イメージセンサ方式のスポットディテクタは今後の スポットディテクタの主流を占めるものと思われるの で以下詳細に述べる。

CCD, すなわち Charged Coupled Device, 電荷結 合度素子が使用されているが，この CCD は 1 個の L SI の中に 256 個の光電子が 図 1 に示すように配列さ れている。セル 1 個のサイズは $17 \mu \times 13 \mu$ であり, 従 来のスポットディテクタの受光セル 1 個に相当する。 このセルが外部からの電気的なシフトパルス（駆動パ
ルス）により，順次左から右に $1,2,3, \cdots \cdots, 256$ とス キャン (走査) され, 光量が電圧に変換されて出力が 外部に取り出される。取り出された電圧波形は図 2 に 示すごとく，均一な光を当てた場合と不均一な光を当 てた場合との様子が画かれている。シフトパルスは $2.5 \mathrm{MHz}$ であり, 図 3 に示すスキャン速度になる。 したがって，セルの信号周期は $110.4 \mu$ 秒になる。

最近の CCD には 1 個の LSI に 256 個セルの 2 倍, 4 倍のものすなわち 512 個， 1,024 個のものが市販さ れ，他の分野ではスポットディテクタ用として使用さ

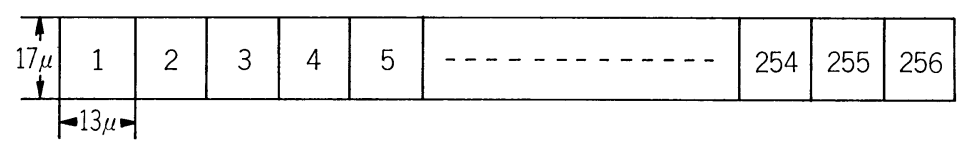

図 1 CCD 1 個とセル 256 個との関係

\begin{tabular}{|l|l|l|l|l|l|l|l|}
\hline 1 & 2 & 3 & 4 & 5 & 6 & 7 & 8 \\
\hline
\end{tabular}

\begin{tabular}{|l|l|l|l|}
\hline 253 & 254 & 255 & 256 \\
\hline
\end{tabular}

C C D素子配列
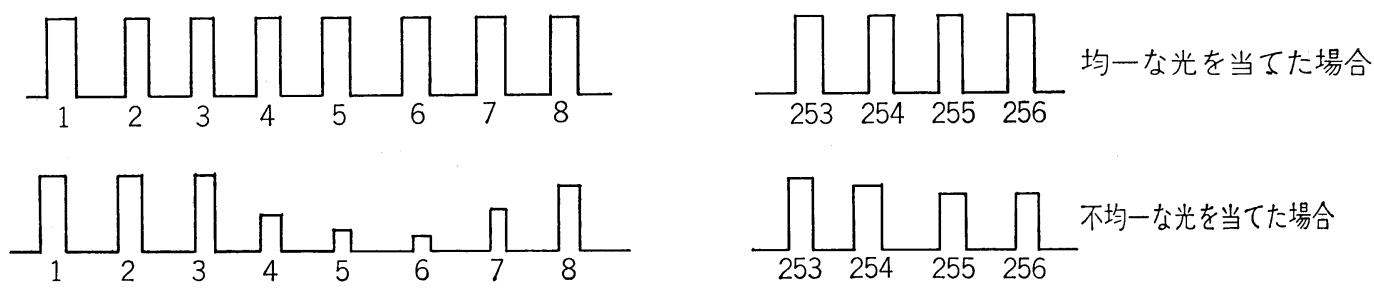

図 $2 \mathrm{CCD}$ に均一な光, 不均一な光を当てた場合の出力電圧概要図 


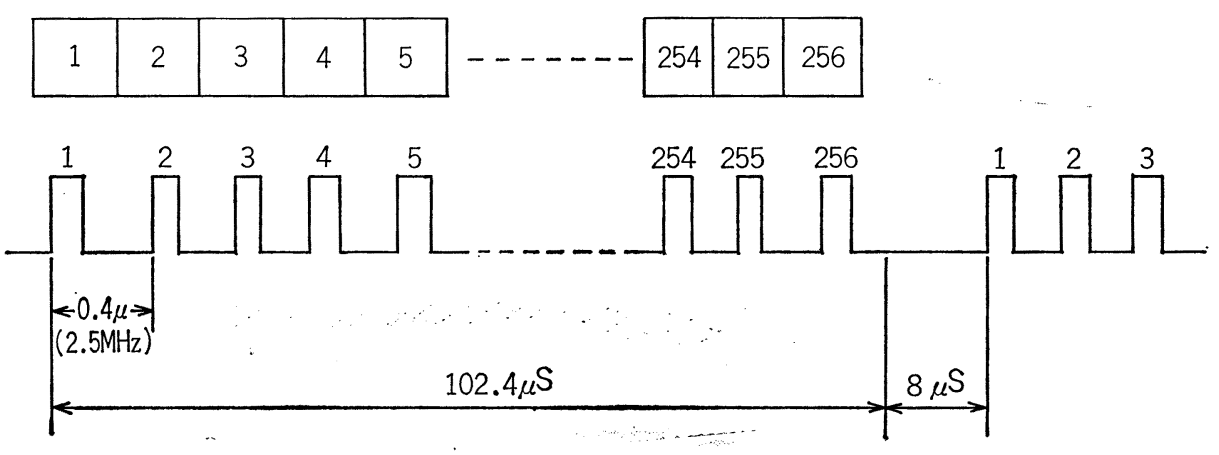

図33 CCD 1 個のスキャン周期

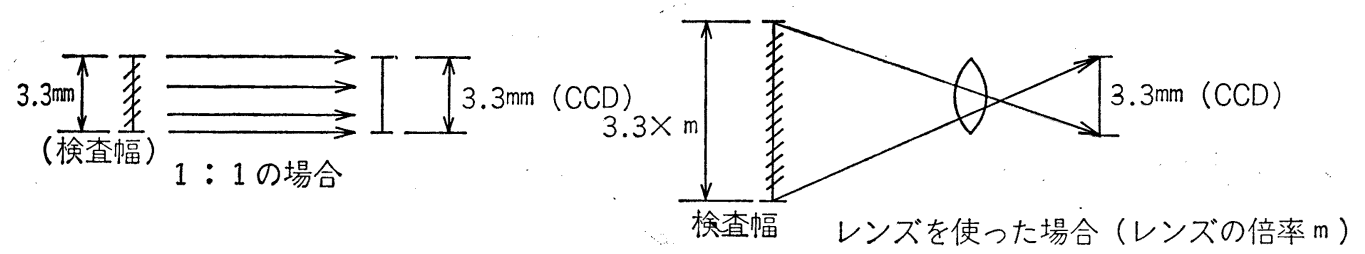

図 $4 \mathrm{~m}$ 倍の場合の概要図

れつつあるが，わが紙パルプの分野では抄紙の速度が

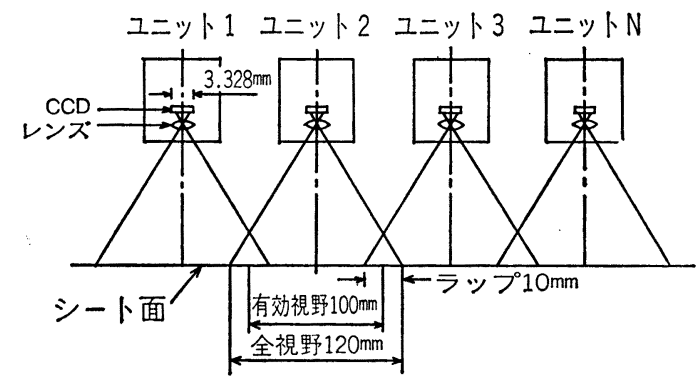

図 5 イメージセンサ概要図
速くなると無理である。すなわち，1個の LSI (以下 素子といら）の幅方向の大きさはセルの数が 256 個の 場合, 1 素子の幅方向の大きさは $13 \mu \times 256 \fallingdotseq 3.3 \mathrm{~mm}$ である。従来のスポットディテクタのごとく現寸法に て使用すれば高感度な測定は可能であるが, 非常に高 価であり，実用的でない。現状ではレンズによる光学 系の拡大により図 4 に示すごとく $\mathrm{m}$ 倍に拡大して使用 している。ユーザから見たポイントは最高 $\mathrm{m} /$ 分 まで OK. であるかといらことであるが, シート流れ方向の 速度 $V(\mathrm{~m} /$ 分 $)=($ セル 1 個の流れ方向の長さ $d) \times(レ$ ンズによる拡大倍率 $m) \div(1$ 個の素子の信号周期 $T) \times$ 60 (秒を分単位に変換), 今ここに $m$

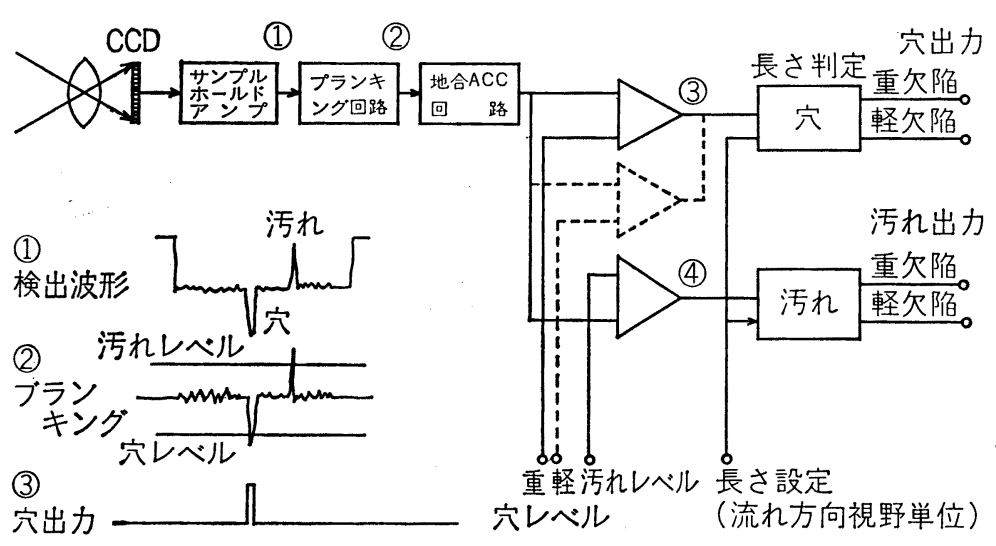

(4)

污れ出力

図 6 イメージセンサ・ブロック図
$=30$, すなわち 1 個素子によるスキャ ン幅 $=3.3 \mathrm{~mm} \times 30 \fallingdotseq 100 \mathrm{~mm}$ の場合

$\mathrm{Vm} /$ 分 $=(17 \times 30 \times 60) \div 110.4$ $=277.2 \mathrm{~m} /$ 分

くポイント>

1）倍率 $m$ を大きくすればより速い シート用に適用できるが, 分解能が悪 くなる。

2) 実務から見て， $m$ が 30 のとき 分解能は $\phi 0.1 \sim 0.2 \mathrm{~mm}$ の黒点である。

図 5 は CCD を使用したイメージセ ンサの概要図(前号では図 34), 図 6 はブロック図を示したものである。ユ 一ザから見たイメージセンサの特長は 次の通りである。 
<ポイント>

1） 欠点信号の中, 光量が多くなる久点である穴, 光量が少なくなる欠点である污れ等に対して検出設定 值を独自に設定できる。さらに，それらの設定值は重 欠点, 軽欠点に分けることができ, 合計 4 つの欠点分 離が可能である。

2）シートから素子までの距離を $100 \mathrm{~mm}$ 以上離せ られるので，オペレータから見て操作性がよい。

3）シートから素子までの駆動をプロセスからのニ ーズおよび経済性に応じて選択できる。通常 100〜 $300 \mathrm{~mm}$ である。

4）レンズを使用した光学系を使用しているので， 特にユーザから見たシートのバタッキに対して誤差が 小さい（通常シートから素子までの距離が $100 \mathrm{~mm}$ の 時,バタッキ $\pm 2 \sim 3 \mathrm{~m} / \mathrm{m}$ では誤差なし)。

5) 図 7 は CCD の各波長に対するスペクトル図で あり, 従来のスポットディテクタと比較して赤味サイ ドの欠点検出が弱い。

6) 図 8 は 1 素子の展開ムラを調査するため全幅 $300 \mathrm{~mm}$ にわたり, 幅 $2 \mathrm{~mm}$ の黒色テープをスキャン 測定した值である。セル 256 個の感度ムラが小さくな ればより高精度な測定が可能になるので，ムラの小さ な LSI をメーカに希望したい。

\subsection{4 薬品回収}

\subsubsection{1 黒液, 緑液, 白液, スラッジ濃度}

現在使用されているタイプとしては「差圧式」「ガ ンマー線式」および「光屈折率式」がある。 <ポイント>

一般的によく使用されているのは「差圧式」であり，

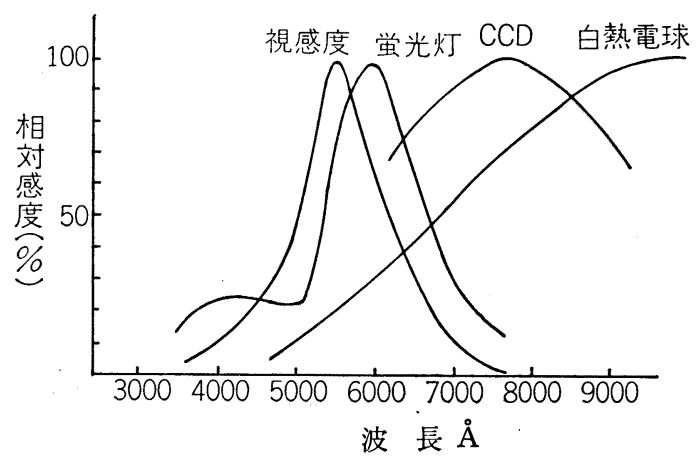

図 $7 \mathrm{CCD}$ 他スペクトル図

サンプリング形とインライン・パイプ形とがある。以 前は「ガンマー線式」がよく使用された。線源の固定 が不完全な場合, 零ドリフトを生ずるので取付には震 動の少ない所に設置すべきである。 また, 気泡および パイプ中のスケールに対して注意を払わなければなら ない。

「光屈折率式」は回収ボイラの黑液等によく使われ ている。接液部のガラス面がよごれた場合の温水洗浄 を考虑する必要がある。また, 最近では図 9 に示すご とく，「振動式」のものが市販された。

\subsubsection{2 振動式}

弦楽器の弦は両端が固定され, 決められた張力で張 られている。したがって, 弦から発する音色は決まっ た周波数となる。すなわち次式で示される。

固有振動数 $f=k \times E \times I / M$ ただし $k$ は常数, $E$ は材料弾性, I はスティフネス, $M$ は質量である。

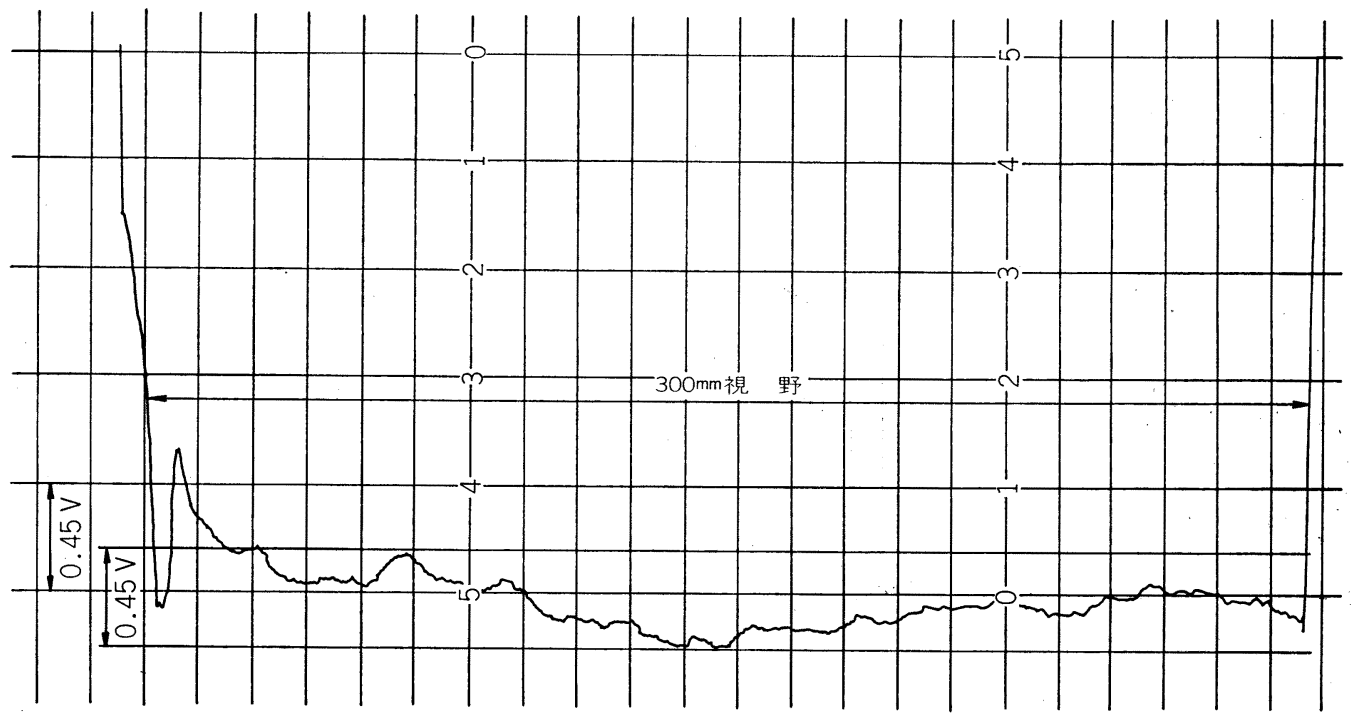

図 8 CCD 1 個, セル 256 個の感度ムラ実測值 


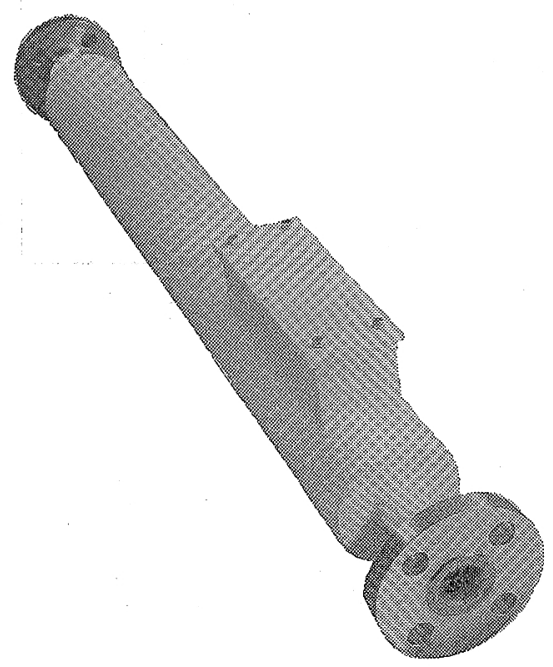

図 9 振動式濃度センサ外観図

(1)式において $k, E ， I$ は一定であるので, 固有振動 数 $f$ は質量 $M$ に逆比例する。振動式セジルおいて 振動素子の重量は一定であるので，振動素子の囲りに 接触する流体の質量すなわち重量の変化に応じて，固 有振動数が変わる。すなわち，体積が一定であれ沙 度に比例して重量は変わるので, 濃度測定が可能にな る。

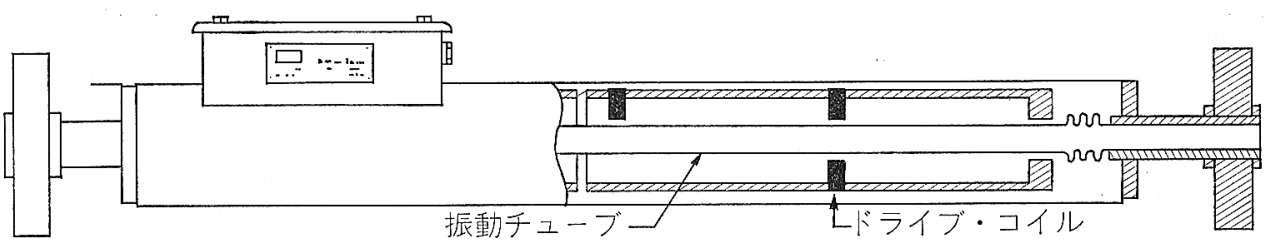

図 10 振動式濃度センサ概要図

表 1 振動式濃度センサの仕様

\begin{tabular}{|c|c|c|}
\hline パラメータ & Type 7830 & Type 7840 \\
\hline 密度レンジ & $0 \sim 3,000 \mathrm{~kg} / \mathrm{m}^{3}$ & $0 \sim 3,000 \mathrm{~kg} / \mathrm{m}^{3}$ \\
\hline 確度 & $0.2 \mathrm{~kg} / \mathrm{m}^{3}$ (range $300 \sim 1,600 \mathrm{~kg} / \mathrm{m}^{3}$ ) & $0.5 \mathrm{~kg} / \mathrm{m}^{3}$ (range $600-1,600 \mathrm{~kg} / \mathrm{m}^{3}$ ) \\
\hline 再 現 性 & $0.02 \mathrm{~kg} / \mathrm{m}^{3}$ & $0.1 \mathrm{~kg} / \mathrm{m}^{3}$ \\
\hline 安 定 性 & $0.2 \mathrm{~kg} / \mathrm{m}^{3}$ per year & $0.5 \mathrm{~kg} / \mathrm{m}^{3}$ per year \\
\hline & typically $-0.01 \mathrm{~kg} / \mathrm{m}^{3} / \mathrm{bar}$ & typically $-0.015 \mathrm{~kg} / \mathrm{m}^{3} / \mathrm{bar}$ \\
\hline & typically $+0.01 \mathrm{~kg} / \mathrm{m}^{3} / \mathrm{bar}$ & typically $+0.02 \mathrm{~kg} / \mathrm{m}^{3} / \mathrm{bar}$ \\
\hline 温度の影響 & $\pm 0.02 \mathrm{~kg} / \mathrm{m}^{3} /{ }^{\circ} \mathrm{C}$ Typical & $+0.7 \mathrm{~kg} / \mathrm{m}^{3} /{ }^{\circ} \mathrm{C}$ Typical \\
\hline & $\pm 0.04 \mathrm{~kg} / \mathrm{m}^{3} /{ }^{\circ} \mathrm{C} \operatorname{Max}$ & $+1.0 \mathrm{~kg} / \mathrm{m}^{3} /{ }^{\circ} \mathrm{C} \operatorname{Max}$ \\
\hline 最大圧力 & 150 bar or as defined by flanges & 50 bar \\
\hline テスト圧力 & 225 bar & 75 bar \\
\hline 温度レンジ & -50 to $+110^{\circ} \mathrm{C}$ & -50 to $+160^{\circ} \mathrm{C}^{*}$ \\
\hline
\end{tabular}

振動秦子に良質な材料を選択し，構造および製作に 充分注意を払い，周困の温度，圧力の影響を受けにく くすれば，Eと $I$ を定に保つことができるので，精 度の高い濃度 (あるいは密度) の計測が可能になる。

・ソラトロン社製濃度センサ

ソラトロン社製濃度センサは上述のポイントを充分 配慮して作られたもので，図 10 はその概要を示した ものである。表 1 は仕様を示したものであり，非常に 高精度な計測が可能である。

\subsubsection{3 その他の濃度センサ}

差圧式，ガンマ一線式，光屈折率，式振動式に続き 「超音波式」などがある。コリオリ式はコリオリの原 理により，し字管のねじれ角が流体の濃度 (密度) に より変化することを利用したものであり，高価な蒜品 濃度の測定に適していると思われる。超音波式は被测 定液中に筀気が含まれないこと，被測定液の物質の粒 度の分布が一定であることがポイントであり，パルプ 濃度用には不適である。

また, 今後の濃度センサとしては紫外線式, 電気伝 導度式，さらに低価格な浮子式なども使用されるもの と思われる。

\section{3 省エネルギー・省資源 センサ}

省エネルギー・省資源用センサとコストダウン用セ その他の実用的な濃度センサとしては「コリオリ式」, 


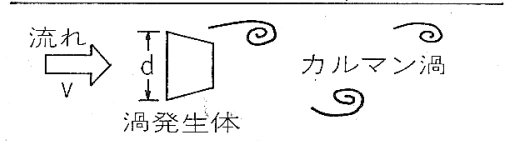

図 11 カルマン渦の発生原理図

ンサとの区別は困難で㠰るが，省エネルギー・省資源 が岒ばれた時代に出現したコストダウン用センサ等に つき述べる。

\subsection{1 洞流量センサ}

流れの中に障害物を置くと流体の粘性の影響で，そ の物体の両側から渦が交互に規則正しく発生する。こ の渦はカルマン渦と言われ，図 11 亿示すごとく発生 する。珮の発生周波数を $f$, 流速を $V$, 洞発生体の流 れに刘向する幅をdとすると，

$$
f=S_{t} \cdot V \cdot d
$$

ここで $S_{t}$ はストローハル数と言われ，レイノルズ数 $R_{e}$ と図 12 亿示すごとく関倸にある。图 12 に扑いて， ストロー八ル数は平坦な範囲が計測籁囲で离り, 流速 は渦の発生周波数に比例する。

次に渦発生体により渦が発生すると，それに比例し

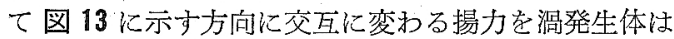
受ける。この揚力を渦発生体が受けるとその中に埋め 込まれた管外の圧電素子に応力として伝わり，圧電勃 果により周期的な電気信号飞変換され，流速が計測さ 礼る。

くポイント〉

センサは導压口や可動部はなく，非常にシンプルで ある。図 14 に示すごとく，珮流量センサ (Yew Flo) の圧力損失㤬従来のオリフィス等の絞り機構のセン少 と比較して非常に小さい。

\subsection{2 超音波ドップラ式流量センサ}

省エネ化が叫ばれた時，プロセスからのニーズは温 水の有效利用をはかるため, 各所の流量を配管を加工 することなく，配管の上から計測することであった。

このニーズに応しただサは,従来の超音波透過型・ ドップラ方式の流速センサではなく，図 15 亿示すご とく反射型のもので就っ。このセンサは国産品仿な く，すべて欧米製であり，当初の $2 \sim 3$ メ一カのも のは上手にいく場合といかない場合とが岁った。

現在実用化されているものは米国ポリソニック社製 のものであり，図16 はその概要図で姆る。

くポイント>

パルプ流量用に使用する場合には，セン步前後に充 分な直管部が必要である。最近では図 17 に示すごと く，清水用のものもポリソニック社から市販された。

\section{3 .3 光学パターン式パルプ流量センサ}

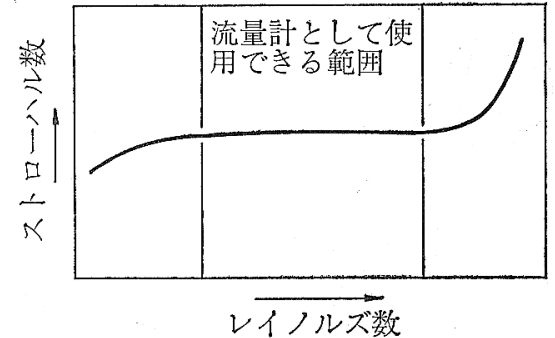

図 12 ストローハル数とレイノルズ数との関係
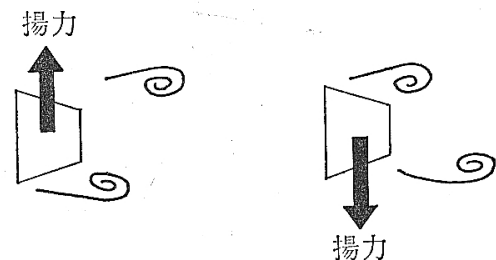

図 13 渦により揚力の概要図

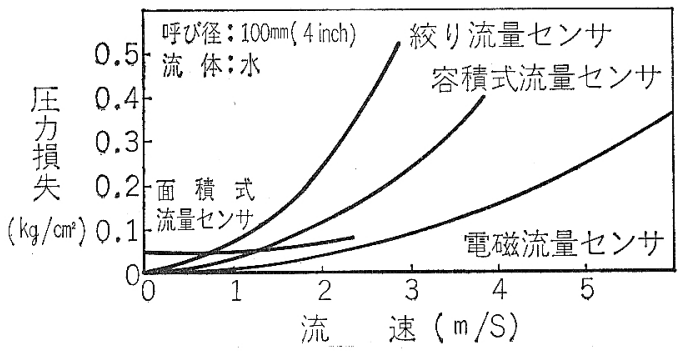

図 14 各種流量センサと圧力損失との関係

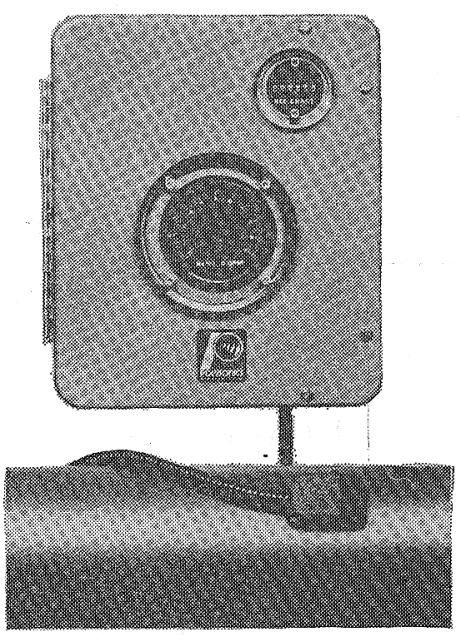

図 15 反射型ドップラ流量センサ外観図

光学パターン式パルプ流量センサは 図 18 に示すご とく $2 つ の$ 光学式光線検知器 $\mathrm{A}$ および $\mathrm{B}$ が，流れ方向 


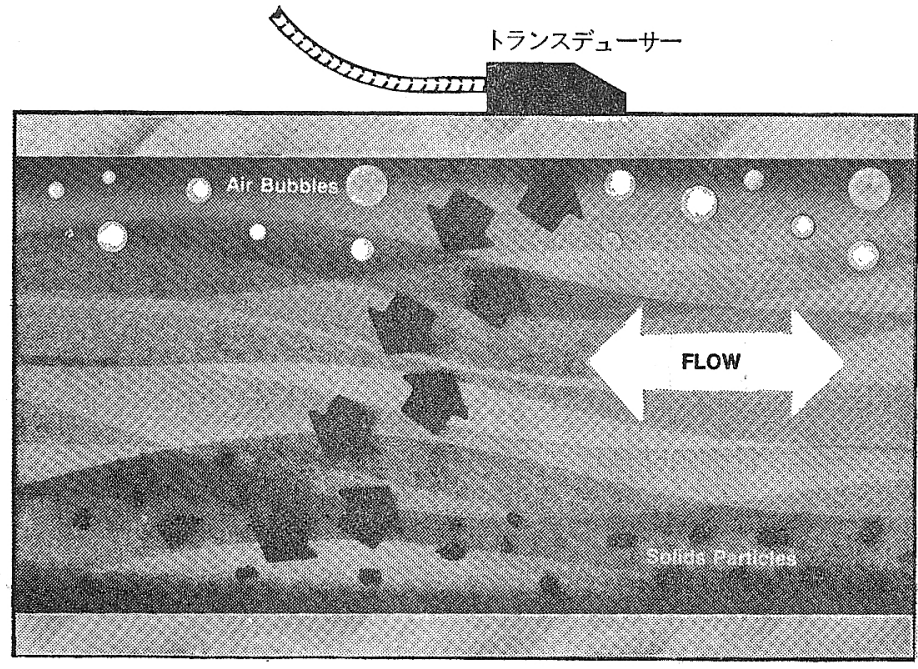

図 16 超音波・反射型・ドップラ方式流量センサ概要図

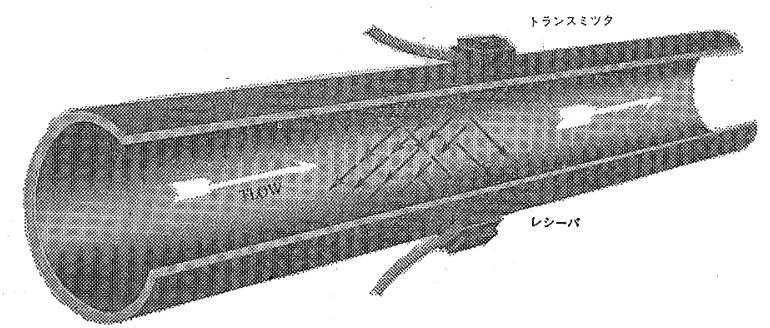

图 17 ポリソニック社製清水用超音波流量セン少概要図
に赥しでパイプの前後にそれぞれ一定 閒隔 $d$ 亿取付的られている。 $\mathrm{A} ， \mathrm{~B} 2$ つの検知器から発する光は流動するパ ルプ液に伝達される。パルプ液中のパ ルプ繊維は 2 つの光線を反射し，反射 光はそれぞれホトダイオードにより電 気信号比変換される。図19 亿示すご とく $\mathrm{A}$ 朽よび $\mathrm{B}$ の信号パターンはほぼ 同一であり，時間差のみ $\Delta t$ である。

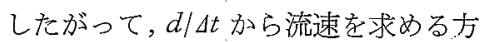
式が本センサの測定原理である。

〈ポイント〉

流量は通常マグナフローにて 測定されているが，口径が大きいと高 価であり，本センサも実用に供するこ とができる。

\subsection{4，低空気比燃焼制御用センサ}

省エネ化が凹ばれている近年，わが 紙パルプ工業においても積極的な省工 ネ化的策が図られているが，その 1 つがボイラ排ガスによる熱損失の減 少である。

ボイラ排ガスの過不足注，通常 $\mathrm{O}_{2}$ ガスセンサ拉よびね゙い㖶浱度センサに より許される值まで，排ガス量学絞る

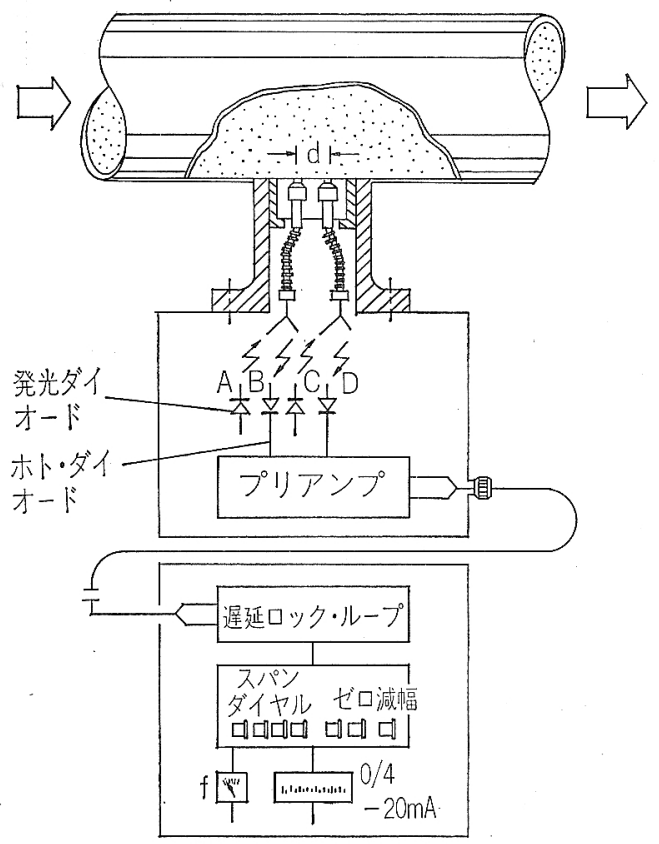

図 18 光学式パルプ流量センサ概要図 ことにより行われている。 $\mathrm{O}_{2}$ センサは磁気式からジ ルコニヤン式へ，サンプリング型からインライン挿入 型へと進展した。

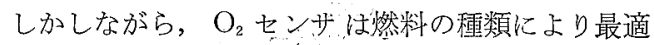
設定值が移動するといら久点がある。そこでクローズ アップされたのが CO ガスセンサである。CO ガスセ ンサは,サンプリング型 (国産品) と光学方式のイン ライン型 (米国製) がある。特にインライン型は煙道 横断・瞬時平均值計測でめり，0.5\% 以下の $\mathrm{O}_{2}$ 制御

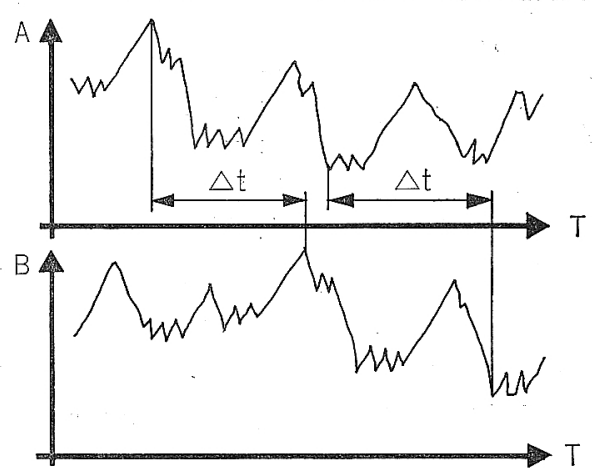

図 19 前後の光学光線检知器で検知された光線 


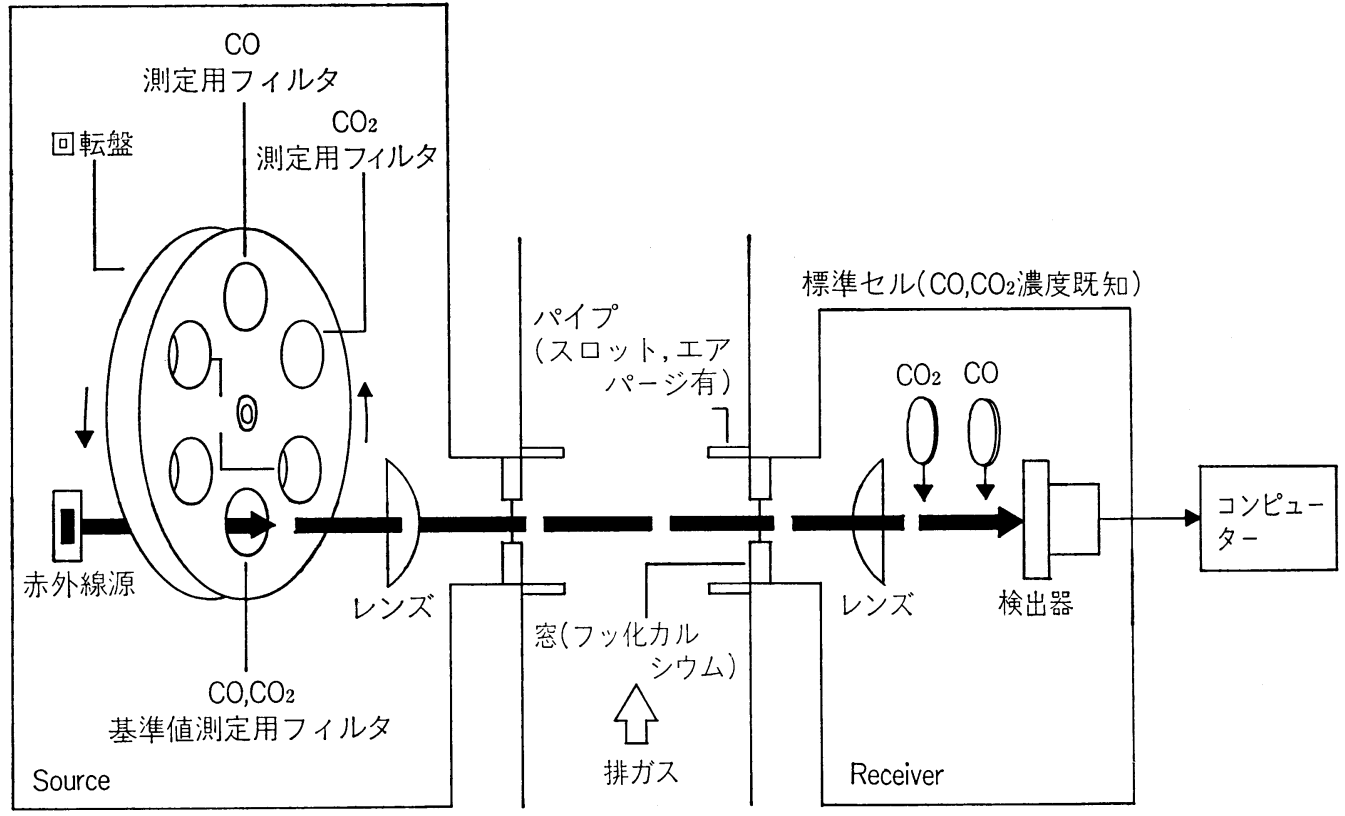

図 20 米国メジャレックス社製 $\mathrm{CO}, \mathrm{CO}_{2}$ ガスセンサ概要図

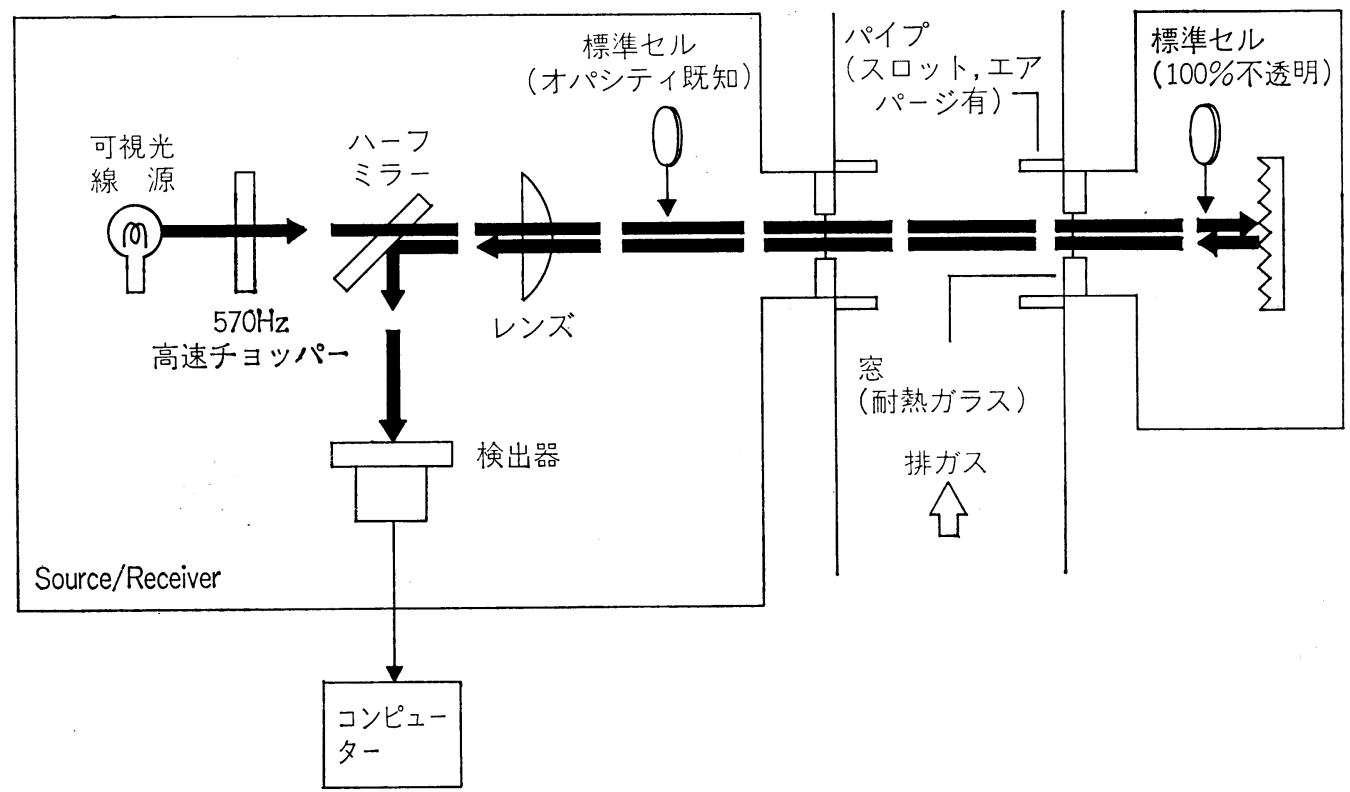

図 21 米図メジャレックス社製オパシティセンサ概要図

を可能にした。

図 20 は米国メジャレックス社製の $\mathrm{CO}, \mathrm{CO}_{2}$ ガスセ ンサ, 図 21 はオパシティ (黒煙濃度) センサの概要 図である。

くポイント>
図 22 は米図 エコーニック社製のセンサである。こ のセンサにて測定されるプロセス值は $\mathrm{CO}$, オパシテ ィ, 排ガス温度および八イドロカーボン (HC) である。 このハイドロカーボンセンサはオパシティセンサと組 み合わされ, バーナーのエアレジスタの空気比の最適 


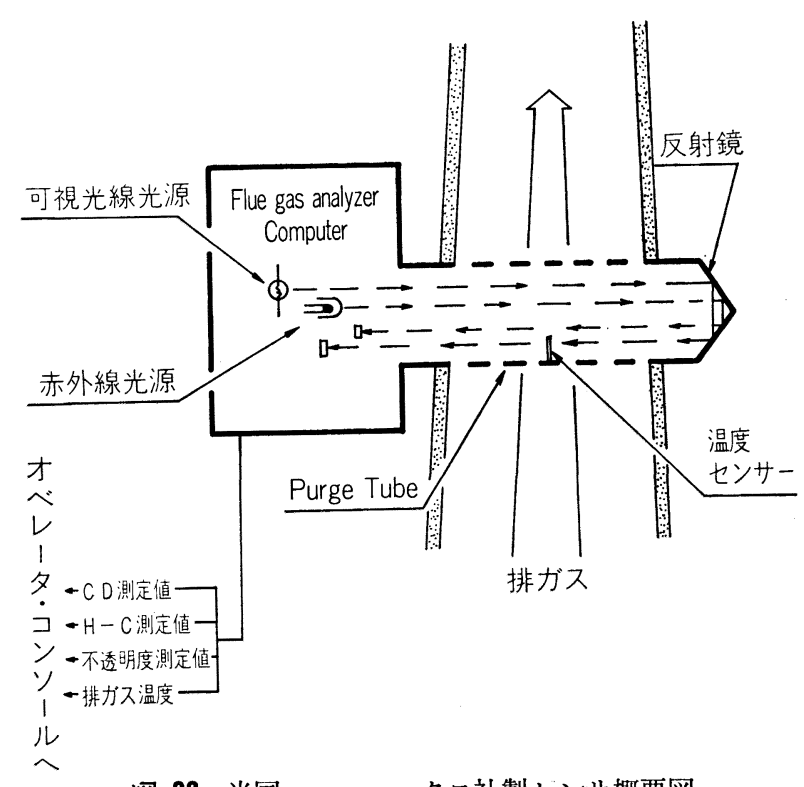

図 22 米国エコーニックス社製センサ概要図
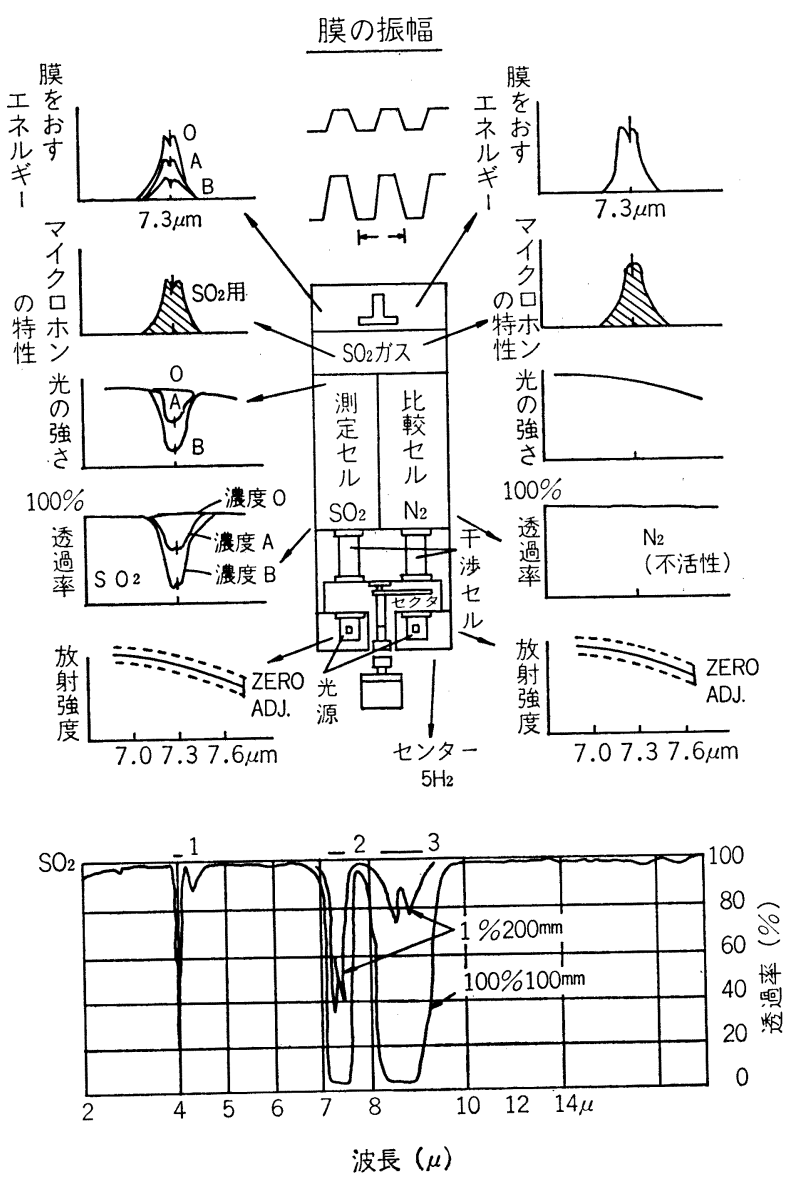

図 23 赤外線方式 $\mathrm{SO}_{2}$ センサ概要図
チューニングに有力なセンサとしてクローズ アップされつつある。

\section{4 環境保全用センサ}

現在法的に義務づけられているセンサとし ては煙道排ガス用として「 $「 \mathrm{SO}_{2}$ センサ」,「N $\mathrm{O}_{x}$ センサ」, 一部の地域では「 $\mathrm{O}_{2}$ センサ」 があり, 排水水質用としては「排水流量セン サ」, 一部の地域では「COD センサ」, 「UV センサ」「「pH センサ」などがある。

\subsection{1 $\mathrm{SO}_{2}$ センサ}

1971年 4 月電気事業法にもとづき，発電ボ イラ 1 缶に 1 台の $\mathrm{SO}_{2}$ センサの設置が義務づ けられた。測定方式としては当初溶液電算率 法が使用されたが，現在ではメンテナンスか ら見て有利な赤外線方式のものが多く使用さ れている。また，紫外線方式のものもある。 図 23 は赤外線方式の概要を示したものであ る。

くポイント>

ユーザから見たポイントはメンテナンス・ フリーのためのガス・サンプリング・システ ムであり，屋外にあるサンプリング配管は電 熱ヒータなどで加温し, ドレン発生の防止を すべきである。

\subsubsection{NOx センサ}

大気污染防止法の施行令の改正により， $\mathrm{N}$ $\mathrm{O}_{x}$ の排ガス基準が定められた。そこで，使 用されている $\mathrm{NO}_{x}$ センサの測定法は, 当初 は低レンジでは高精度である化学発光法であ ったが，その後赤外線方式も高精度になり， さらにメンテナンスから見て有利になったの で使用されるようになった。また，柴外線吸 収法もある。

ユーザから見たポイントは, $\mathrm{SO}_{2}$ センサの 場合と同様，試料ガスのサンプリング・シス テムのドレン発生防止のためのヒータ加温で ある。

\section{4 .3 排水污濁用センサ}

水質污濁計測用として使用されている $\mathrm{CO}$ $\mathrm{D}$ センサは現在東京湾, 伊勢湾, 瀬戸内海一 流れる河川に工場排水を流寸工場，事業所な どはすべて設置が義務づけられている。

COD とは, “化学的酸素要求量すなわち水 中の被酸化物が酸化する際に消費される酸素 量 $(\mathrm{mg} / l, \mathrm{ppm})$ を言う。測定法としては各 種のものがあるが, 図 24 にその一例の概要 


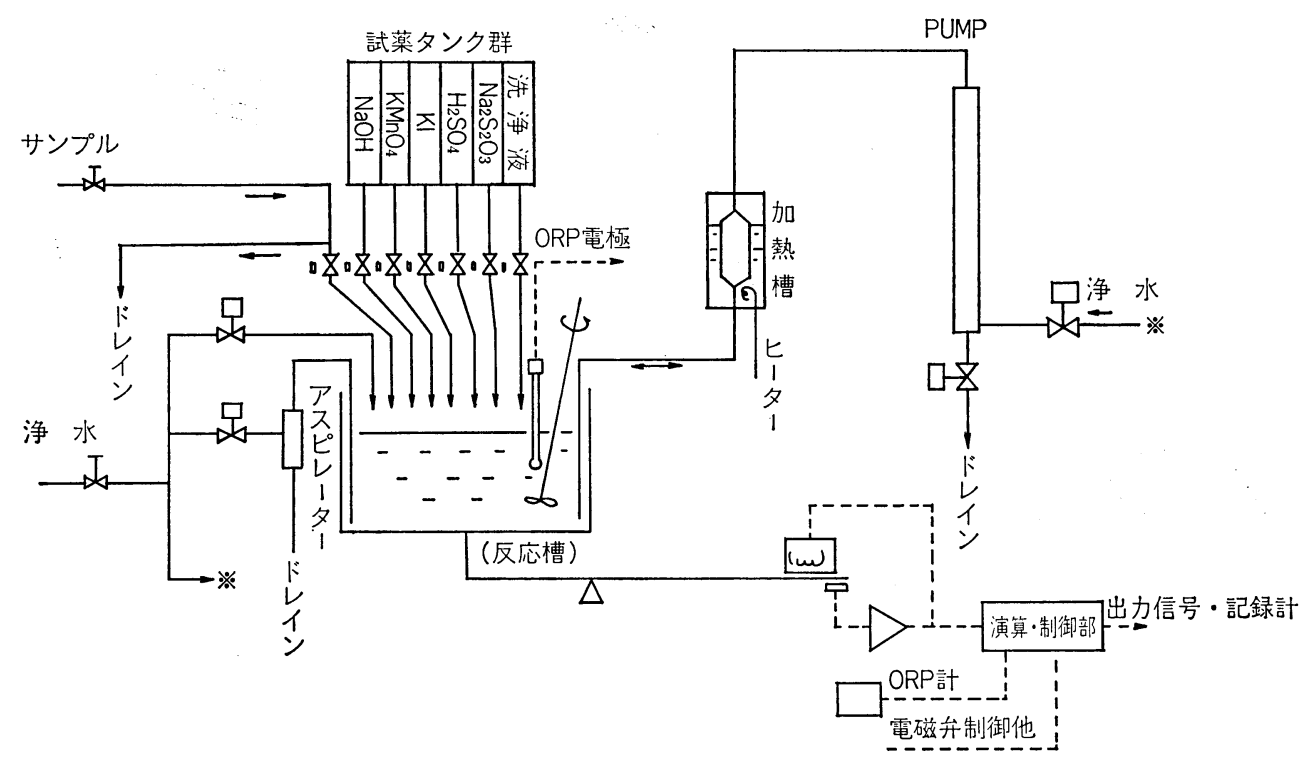

図 $24 C O D$ センサ概要図

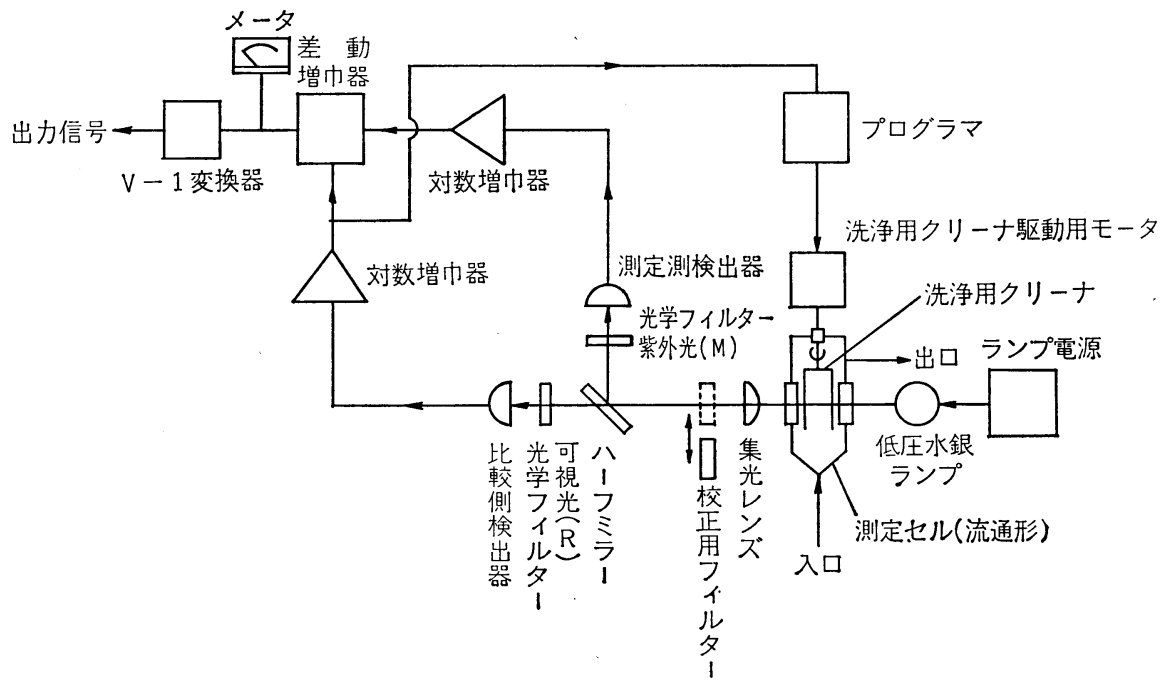

図 25 UV センサ概要図

を示した。

\subsubsection{UV センサ}

上述の COD センサはユーザから見て，メンテナン スが面倒であること，銀を使用するのでメンテナンス 費用が高いことなどの理由により，本測定法がクロー ズアップされてきた。

紫外線式有機污濁センサは紫外線吸光度により, 水 中の有機物湦度のみを連続的に測定する装置であり,

一般にUV センサと呼ばれている。UV センサは保 守が容易なものが市販され好評である。
図 25 はUV センサの概要を示したものである。ゼ 口点校正は水道水を, スパン校正は内蔵された光学フ ィルタの使用により, 簡単な操作でできるようになっ ている。セルの空は露結しないように低温モールドヒ 一タにて常時加温されている。光源 ランプは $60^{\circ} \mathrm{C} \pm$ $0.2^{\circ} \mathrm{C}$ に制御され, 光源の輝度変化を少なくしている。 くポイント>

ユーザから見て UV センサがなせ COD センサに 代行して有機物濃度を測定できるのかといらことであ るが，以下がその解答である。 


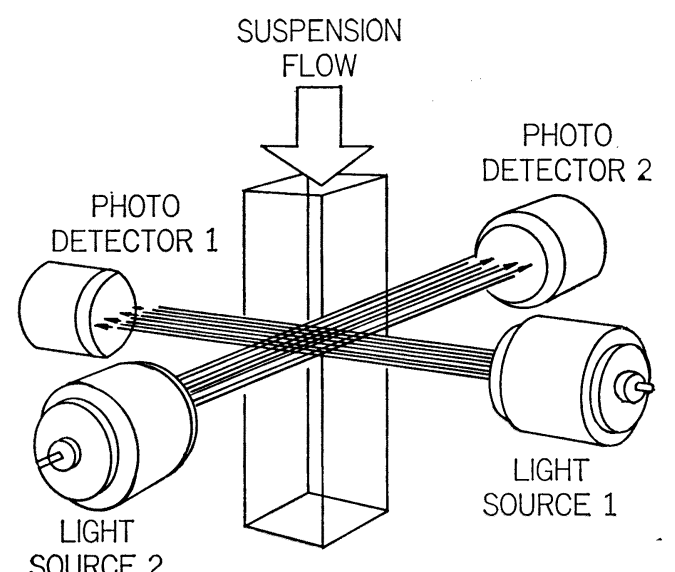

SOURCE 2

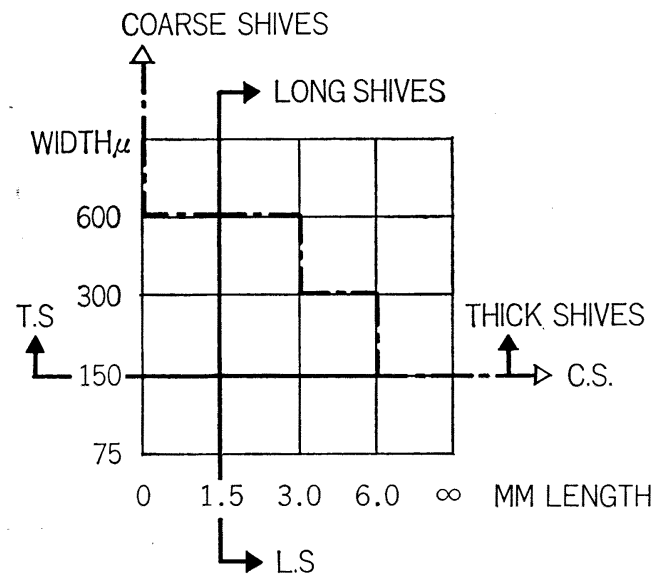

図 26 米国 SCA コントロール システム 社製メカニ カルパルプ用繊維の長さ, 太さ, その分布用 センサ概要図

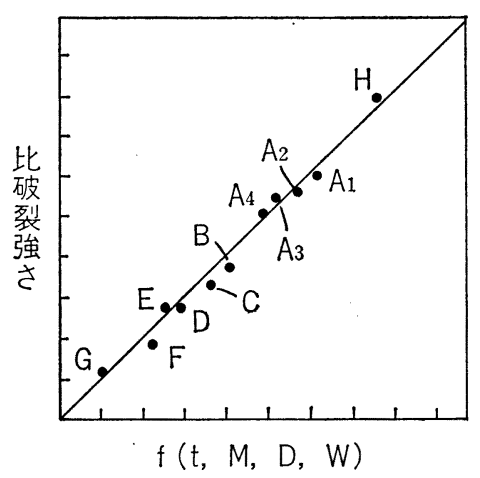

図 27 各種紙の比破裂強さ

有機物質は分子構造によりそれぞれ異なる紫外線吸 収スペクトルを持つ。一般に二重結合を持つ環式化合
物では紫外線の吸収は大きく，二重結合を持たない鎖 式化合物では小さい。

水素イオン, 塩素イオン等の無機イオンは $250 \mathrm{~nm}$ 以上の波長での吸収は無く, 有機物のみによる。

紫外線の吸収と有機物の濃度との関係は普遍的なも のはなく, 吸光度の係数は物質により異なる。したが って, 排水の中に含まれている種々ら吸光度を持つ有 機物の構成割合が一定であるかどうかが,この低価格・ メンテナンスフリーの UV センサを使用できるかど らかのポイントである。

\section{5 その他のセンサ}

製紙プロセスは天然資源である木材およびその繊維 を取り扱い，それを主原料として狭い幅から広い幅 で，低速度から高速度まで，わが国では約 1,500 台の 抄紙機にてペーパーシートを抄造している。そこでの 原料やペーパーシートの品質のバラッキは大きく, し たがって局部的な計測のみで全体を代表させるには困 難であった。以上の点がわが紙パルプ計装の進展を促 した。

センサの最後の項として，これから期待されるセン サにつき展望したい。

\section{5 .1 ペーパーシート・全幅プロファイル・瞬時} 計測用センサ

筆者は抄紙機リールにて全幅の水分ムラをサーモグ ラフィ（熱画像）によるカラーCRT 表示に成功した が，これからは坪量等他のプロセス值も表示できるこ とを期待したい。

\subsection{2 紙の主原料である纎維の 1 本, 1 本の長さ,} 太さ等の計測さらに一定体積中の分布計測 用センサ

図 26 はスウェーデン国, SCA コントロールシステ ム社にて開発されたあのであり,メカニカルパルプの 繊維の長さ,太さ，分布の計測用センサの概要図であ る。

\subsection{3 ペーパーシート用粘弾性テスタ}

筆者も十数年前ペーパーシートの超音波による紙力 測定にアプローチしたが, 最近ではN 商事でも積極的 に取り組んでいる。

ペーパーシートの応力と伸びとの関係は非直線であ り,さらに一定応力では継続的にのびる。一例として, 引張り試験器を使用して紙片を試験した場合, $10 \mathrm{~kg}$ 4 秒で切れる同一サンプルを, 他の条件ではそれぞれ $9 \mathrm{~kg}$ の場合 11 分, $8 \mathrm{~kg}$ では 14 時間, $4 \mathrm{~kg}$ では 200 日で裂断するというょうに, 伸びと与える応力速度に より, その関係は変化する。すなわち, 紙の品質は非 常に複雑な変形および流動現象を示すのでレオロジー 


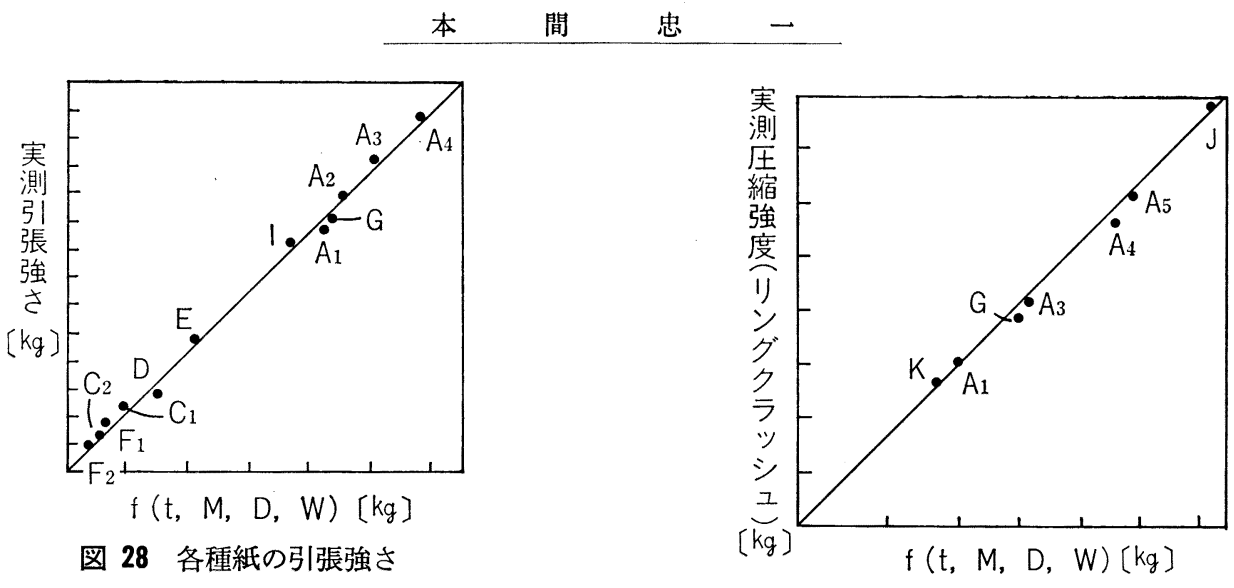

的アプローチが適用できる。今後のオンライン用を考 慮するとセンサとしては超音波式が有利である。図 27 ３1は従来の破壊試験器と本方向による超音波式非破 壊方式による相関図である。

すなわち, 紙中を伝わる音速 $(t)$ を計測し, さらに 紙の密度 $(D)$, 米坪 $(W)$, 水分 $(M)$ にて補正演算 することにより紙の弾性率を求め, この弾性率と紙の 力学的強度との関係を実験により求めたものである。

今後, 紙の粘性係数の計測が可能であれば, 市場か ら見た紙の品質が数值的なニーズとなりプロセスの 管理の数值化が可能になる。

さらに最終製品の力学的性質が的確に推定可能にな り, 売れる製品をより安価に抄造できる有力な武器と なろら。

\section{5 .4 アイソトープ 線源である $\beta$ 線を使用しない}

\section{安価な坪量センサ}

$\beta$ 線は放射線であり, 法的にユーザから見て取扱主 任技術者が必要である。現在わが国では 1,500 台の抄 紙機のらち， $\beta$ 線を使用しているものは $20 \%$ 強と推 定され，残りの抄紙機の大部分のものは現状では $\mathrm{BM}$ 計は設置されていない。

今後設置する場合は低価格であること，取扱主任技 術者不要であることを望んでいる。

これらのニーズに応じるものとして赤外線, マイク 口波, 限界線などのものが出現するものと思われる (一部市販されだした)。

(続く)

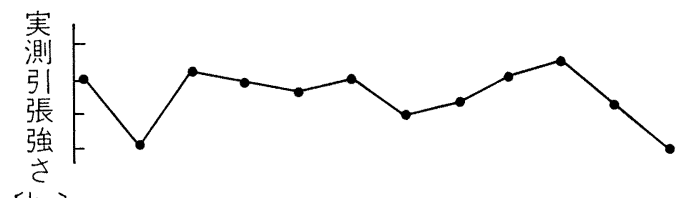

[kg]

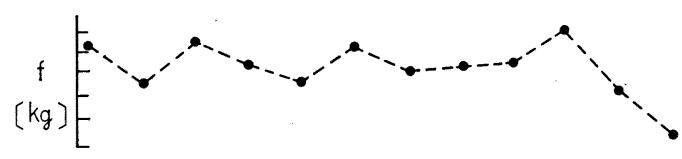

図 31 同一銘柄である「ライナー」の引張強さ の相関図 